\title{
Integrated Marketing Communication Analysis and Its Effect Towards Brand Equity
}

\author{
Perwito $^{1, *}$ Agus Rahayu ${ }^{2,}$ Heny Hendrayati ${ }^{3}$
}

\author{
${ }^{1}$ Universitas Pendidikan Indonesia \\ ${ }^{2}$ Universitas Pendidikan Indonesia \\ ${ }^{3}$ Universitas Pendidikan Indonesia \\ ${ }^{*}$ Corresponding author.Email:perwitoe@upi.edu
}

\begin{abstract}
Gojek is one of the transportation platforms, food and beverage delivery services, in running for business implementing Integrated Marketing Communication (IMC), the usage of applications on cell phones or smartphones based on internet technology will provide convenience in service and communication processes with customers. The objective of this paper is to examine, integrated marketing communication analysis and its effect toward brand equity from the customer perspective. This study uses a quantitative approach, an explanatory survey type and descriptive verification. Simple random sampling technique of this study, from 290 of the Piksi Ganesha Polytechnic students. Data analysis techniques use; data normality test, correlation test, regression, and hypothesis testing. The results of the analysis; show that Integrated Marketing Communications (IMC) have a positive and significant effect on Brand Equity (BE). It is important to focus on the company which continues to take strategic actions related to the Integrated Marketing Communication (IMC), so that the company's Brand Equity is increasingly in the minds of consumers, which can improve the company's performance that is reflected in the optimization of sales, profits, and wealth to shareholder value.
\end{abstract}

Keywords: Integrated Marketing Communication, Brand Equity, information and communication technology.

\section{INTRODUCTION}

Internet users in Indonesia have increased from year to year. This is evidenced by a survey conducted by the Indonesian Internet Service Providers Association (APJII). The total population of 264 million citizens in Indonesia, there are 171.17 million people or around 64.80 percent who have been connected to the internet. This figure increased by $10.12 \%$ from 2017 amounting to only $54.68 \%$. The use of the application is dominated by young men or commonly called millennial groups with an age range of 17-24 years that have characteristics typical 3C namely; Creative, Confidence, and Connected $[1,2]$.

Brand Equity (BE) is an intangible asset and a valuable asset owned by the company, the strength of Brand Equity greatly influences the creation of corporate value (Corporate Value Creation), by having good Brand Equity, the company has already been superior competitiveness that is good, so that business continuity is increasingly strong [3-5]. Marketing investments on brand equity significant provides a host of benefit for firm performance and ultimately wealth shareholder value $[6,7]$.

Increasing levels of competition between Gofood and Grabfood. Reference [2] research provides empirical evidence that; Gofood; brand image level $70.9 \%$, loyalty $69.9 \%$, engagement 68.9, and performance 69.9 , while Grabfood; the brand image level is $69.0 \%$, loyalty $68.9 \%$, engagement 68.1 , and performance 68.7. GoFood leads in millennials with higher awareness, usage, and customer loyalty compared to competitors. Gofood as a pioneer, if you have to maintain the strength of brand equity as a market leader, then in carrying out marketing communications and especially in the millennial generation has to use Integrated Marketing Communication (IMC).

Seeing the condition and development of existing information technology rapidly, industry players need to consider what strategies or media are still relevant to 
their products while looking at the extent to this marketing method develops through existing digital platforms. The role of promotion in the company is very important because it will establish a good communication process between product providers and consumers. An effective product delivery process, an important company implements Integrated Marketing Communication (IMC) and needs to be designed and done well, so that it will have a positive impact on the company's Brand Equity [3, 8-11].

Integrated marketing communication can contribute to brand equity by building a brand in memory and creating a brand image. Marketing communication carried out effectively can strengthen brand equity so that it will ultimately increase company value [3, 8-13].

Integrated Marketing Communication (IMC) in this study aligns with the development of information and communication technology which is characterized by online and social media marketing indicators, mobile marketing, direct and database marketing [9]. Based on the data and problems above, whether the e-promotion conducted by Gojek results in the perception that Integrated Marketing Communication (IMC) influences Brand Equity (BE).

The study of this article focuses on "integrated marketing communication analysis and its effect toward brand equity". We compiled this article into; section 1 introduction, section 2 describes methods, section 3 discusses the results and discussion, section 4 conclusions.

\section{METHODS}

This study uses a marketing management approach specifically regarding the relationship of Integrated Marketing Communications (IMC) and Brand Equity (BE). The research method uses explanatory survey and descriptive verification $[14,15]$. The variables in this study, namely; Integrated Marketing Communications (IMC) and Brand Equity (BE). Referring to the theoretical study, the operationalization of research variables can be formulated as the Table 1 .

Operationalization of Research Variables

\begin{tabular}{|c|c|c|}
\hline Consept & $\begin{array}{l}\text { Theoritis } \\
\text { Concept }\end{array}$ & Empirical Concept \\
\hline $\begin{array}{l}\text { Integrated } \\
\text { Marketing } \\
\text { communicat } \\
\text { ions (IMC) }\end{array}$ & $\begin{array}{l}\text { Integrated } \\
\text { Marketing } \\
\text { communications } \\
\text { are the means by } \\
\text { which firms } \\
\text { attempt to inform, } \\
\text { persuade, and } \\
\text { remind consumers } \\
\text { directly or } \\
\text { indirectly about } \\
\text { the products and } \\
\text { brands they sell } \\
{[11] .}\end{array}$ & $\begin{array}{l}\text { The IMC Likert model total } \\
\text { score is } 5 \text { points with } \\
\text { indicators. } \\
\text { Advertising: } \\
\text { amplified expressiveness, } \\
\text { control } \\
\text { Sales promotion; ability to be } \\
\text { attention getting, incentive, } \\
\text { invitation } \\
\text { Events and experiences; } \\
\text { relevant, engaging, implicit } \\
\text { Public relations and } \\
\text { publicity; high credibility, } \\
\text { ability to find hard-to-reach }\end{array}$ \\
\hline
\end{tabular}

\begin{tabular}{|c|c|c|}
\hline Consept & $\begin{array}{l}\text { Theoritis } \\
\text { Concept }\end{array}$ & Empirical Concept \\
\hline & & $\begin{array}{l}\text { buyers, dramatization } \\
\text { Online and social media } \\
\text { marketing; rich, interactive, } \\
\text { up to date } \\
\text { Mobile marketing; timely, } \\
\text { influential, pervasive } \\
\text { Direct and database } \\
\text { marketing; personal, } \\
\text { proactive, complementary } \\
\text { Personal selling; customized, } \\
\text { relationship oriented, result } \\
\text { oriented }\end{array}$ \\
\hline $\begin{array}{l}\text { Brand } \\
\text { Equity (BE) }\end{array}$ & $\begin{array}{l}\text { References [3, } 13, \\
16] \text { defining brand } \\
\text { equity as: "Is a set } \\
\text { of brand assets } \\
\text { and liabilities. Is } \\
\text { linked to the } \\
\text { brand's name and } \\
\text { symbol. Can } \\
\text { subtract from, as } \\
\text { well as add to, the } \\
\text { value provided by } \\
\text { a product or } \\
\text { service. Provides } \\
\text { value to customers } \\
\text { as well as to a } \\
\text { firm }\end{array}$ & $\begin{array}{l}\text { The BE Likert model total } \\
\text { score is } 5 \text { points with } \\
\text { indicators. } \\
\text { Brand awareness; } \\
\text { Perceived quality; } \\
\text { Brand associations; } \\
\text { Brand loyalty; }\end{array}$ \\
\hline
\end{tabular}

The population in this study were 1042 active students in the Computerized Accounting Study Program of Piksi Ganesha Polytechnic. The research sampling technique used simple random sampling of 290 students. The main data source in the study was obtained from a questionnaire through Google Form conducted in October and November 2019. The secondary data used in the study such as; literature studies, scientific articles/journals, and relevant publication in this research.

Data analysis techniques used descriptive and inferential statistical approaches. The stages are; Test the validity and reliability of the Instrument, descriptive statistics, and Inferential Analysis; Data normality test, correlation test, regression test, and statistical hypothesis test using the $t$ test. the statistical hypothesis of this study is;

- Ho: $\rho=0, \quad$ Integrated Marketing Communications $=$ IMC has no significant effect on Brand Equity $=\mathrm{BE}$

- Ha: $\rho \neq 0, \quad$ Integrated Marketing Communications = IMC has a significant effect on Brand Equity $=\mathrm{BE}$

\section{RESULTS AND DISCUSSION}

\subsection{Data Result}

The overall analysis results of Integrated Marketing Communications and Brand Equity as Table 2. 
Table 2. Integrated Marketing Communications and Brand Equity

\begin{tabular}{|l|l|l|l|}
\hline No & \multicolumn{1}{|c|}{ Dimension } & \multicolumn{1}{|c|}{ Average } & Category \\
\hline 1 & Advertising & 3,56 & Good \\
\hline 2 & Sales promotion & 3,27 & Good \\
\hline 3 & Events and experiences & 3,28 & Good \\
\hline 4 & $\begin{array}{l}\text { Public relations and } \\
\text { publicity }\end{array}$ & 3,30 & Good \\
\hline 5 & $\begin{array}{l}\text { Online and social media } \\
\text { marketing }\end{array}$ & 3,63 & Good \\
\hline 6 & Mobile marketing & 3,29 & Good \\
\hline 7 & $\begin{array}{l}\text { Direct and database } \\
\text { marketing }\end{array}$ & 3,26 & Good \\
\hline 8 & Personal selling & 3,53 & Good \\
\hline Amount IMC & $\mathbf{3 , 3 9}$ & Good \\
\hline 1 & Brand awareness & 3,40 & Good \\
\hline 2 & Perceived quality & 3,38 & Good \\
\hline 3 & Brand associations & 3,37 & Good \\
\hline 4 & Brand loyalty & 3,34 & Good \\
\hline Amount $\boldsymbol{B E}$ & $\mathbf{3 , 3 3}$ & \\
\hline
\end{tabular}

Based on Table 2 it can be explained that an average score IMC of 3.39 is obtained and good category, and average score BE of 3.33 and in good category.

Based on Table 3 it can be explained that; Asym Sig value. (2-tailed) for both of these variables $>0.05$, Thus both variables are declared normally distributed. The relationship of variable Integrated Marketing Communications (IMC) variable with variable Brand Equity (BE) obtained a positive relationship that is equal to 0.988 and it is in the very strong category. The value of R Square (Coefficient Determination) is 0.977, this shows that IMC affects Brand Equity $97.70 \%$, and the remaining $2.30 \%$ is influenced by other factors outside this study. a constant of 2.448 states that if there is no IMC it is not implemented properly, then Brand Equity is 2.448. While the regression coefficient of 0.841 states that every time the IMC is added, the Brand Equity will increase by 0.841 and vice versa. To determine the criteria for decision making on the proposed hypothesis, the results of the analysis of the value of $0,000<0.05$ then $\mathrm{H} 0$ is rejected, thus it can be concluded that the IMC has a positive and significant effect on Brand Equity.

Table 3. Summary Result Hypothesis Testing

\begin{tabular}{|l|l|l|}
\hline \multicolumn{1}{|c|}{$\begin{array}{c}\text { Variable / } \\
\text { Description }\end{array}$} & \multicolumn{1}{|c|}{ p-value } & \multicolumn{1}{c|}{$\begin{array}{c}\text { Hypothesis } \\
\text { Result }\end{array}$} \\
\hline IMC & 0.053 & Normal \\
\hline BE & 0.068 & Normal \\
\hline $\begin{array}{l}\text { Pearson } \\
\text { Correlation }\end{array}$ & 0.988 & Very strong category \\
\hline $\begin{array}{l}\text { Adjusted R } \\
\text { Square }\end{array}$ & 0.977 & Very High category \\
\hline p-value / t value & $0.000 / 109.894$ & Supported \\
\hline
\end{tabular}

Source: data analysis, 2019.

\subsection{Discussion}

Promotion is part of marketing as outlined in the marketing mix concept or it is often called the marketing mix as explained above [17]. Promotion refers to activities that communicate the merits of the product and persuade the target customers to buy it. To be easily applied to companies, promotions have been accompanied by using promotional tools. The specific blend of promotion tools that the company uses to persuasively communicate customer values and build customer relationships, the Promotion Mix is also known as the marketing communication mix.

Along with the development of digital technology has led to extraordinary changes in the way companies and customers communicate. The digital age has given birth to a number of new information and communication tools, from satellite and cable television to Internet-based smartphone and tablet media (website brands, email, blogs, social media and online communities, mobile web, and many others).

For example, likes mass marketing which has led to a new generation of mass media communication, the new digital and social media have given birth to more dynamic social media. The means of marketing communication that companies use in an effort to inform, persuade, and remind consumers about the products and brands they sell are also changing.

Along with market competition, products that have strong brand equity will be able to compete, seize, and control market power. Elements knowledge of brand equity and the measurement is needed to devise strategic steps in increasing the existence of a brand that can ultimately increase company profitability. One way to do strengthening the company's brand is promotion.

Brand Equity (BE) is an intangible asset and a very valuable asset owned by the company, the strength of brand equity influences the Corporate Value Creation, by having a good brand equity, the company has already been good competitive advantage, so that business continuity is getting stronger.

A positive assessment of technology platforms such as Gojek-Gofood will certainly have a sustainable positive impact on their business amid changes in consumer behavior, especially in the millennial generation segment. Go-food inter-food messaging service products that have been built well in the minds of consumers with aspects of Go-food technology that are considered prime or superior.

The results of the analysis show that the relationship between Integrated Marketing Communication (IMC) and Brand Equity (BE) is very strong, it is important to note that companies always take strategic actions related to the Integrated Marketing Communication mix so that Equity The company's brand is increasing in the minds 
of consumers, which can improve corporate performance ultimately, this research relevant with [10, 18, 19]. Brand Equity mediates the relationship between Integrated Marketing Communication (IMC) and brand performance (BP) [20].

Integrated marketing communication can contribute to brand equity by building a brand in memory and creating a brand image. Promotion or marketing communication carried out effectively can strengthen the perception and brand equity of the company, so that in the end it will optimize sales, profits, increase the value of the company which leads to prosperity for shareholders [3, 4, 9-13, 21, 22].

Instead, brand managers should assign more weight to the potential of engaging stakeholders to build brand value, in the form of dynamic capabilities. To achieve competitive advantage, brand managers should be develop stakeholder strategies that cultivate unique dynamic capabilities [4]. Along with the development of current technology, methods and media in marketing, especially marketing communication strategies change from traditional ways to be technology based. Produced research that Information and Communication Technology (ICT) mediates integrated marketing communication (IMC) to brand equity (BE), this shows that if a company implements and updates the technology it can improve and speed up the process of marketing communication to customers rapidly $[8,9]$. Social media and the application of information technology has become an integral part of business and marketing strategies, social media communications strongly influence brand image. Social media marketing management will cultivate the brand community upon which customers rely on as an most important source of information in decision making [23]. Social media marketing activities have a significant impact on consumer-based brand equity [24, 25]

Integrated marketing communication activities have to be be carried out by the company because marketing communication becomes the central point and strategy in building the company's image, [26] many various choices can be made to communicate to customers. In order for this activity to run effectively, regularly and ongoing evaluations are important to do

\section{CONCLUSION}

The results showed that Integrated Marketing Communication $=$ IMC had a positive and significant effect on Brand Equity = BE can improve company performance which is reflected in the optimization of sales, profits, and prosperity of the company's owners. Suggestions of this research are; data analysis using SEM so that it can be seen which indicators most influence the formation of Brand Equity, and Application of communication information technology to be a mediating variable in strengthening Brand Equity.

\section{ACKNOWLEDGMENTS}

The highest gratitude and appreciation to the Graduate School of the Indonesian University of Education, lecturers supporting the subjects, and those who have helped in the completion of the research

\section{REFERENCES}

[1] APJII, "Penetrasi \& Profil Perilaku Pengguna Internet Indonesia," Apjii, 2017.

[2] S. Alvara, "Perilaku dan preferensi konsumen millennial indonesia terhadap aplikasi e-commerce 2019," 2019.

[3] D. A. Aaker, "The value of brand equity," J. Bus. Strategy, vol. 13, no. 4, pp. 27-32, 1992.

[4] H. M. D. Wang and S. Sengupta, "Stakeholder relationships, brand equity, firm performance: A resource-based perspective," J. Bus. Res., vol. 69, no. 12, pp. 5561-5568, 2016.

[5] S. Nana, R. T.- Mamina, N. Chiliya, and E. T. Maziriri, "The impact of corporate rebranding on brand equity and firm performance," J. Bus. Retail Manag. Res., vol. 13, no. 04, pp. 155-172, 2009.

[6] K. L. Keller and T. O. Brexendorf, Measuring Brand Equity. 2019.

[7] D. H. M. Wang, P. H. Chen, T. H. K. Yu, and C. Y. Hsiao, "The effects of corporate social responsibility on brand equity and firm performance," J. Bus. Res., vol. 68, no. 11, pp. 2232-2236, 2015.

[8] M. Šerić and I. Gil-Saura, "ICT, IMC, and Brand Equity in high-quality hotels of Dalmatia: An analysis from guest perceptions," J. Hosp. Mark. Manag., vol. 21, no. 8, pp. 821-851, 2012.

[9] M. Šerić, I. Gil-Saura, and M. E. Ruiz-Molina, "How can integrated marketing communications and advanced technology influence the creation of customer-based brand equity? Evidence from the hospitality industry," Int. J. Hosp. Manag., vol. 39, pp. 144-156, 2014.

[10] K. Mongkol, "Integrated marketing communication to increase brand equity: The case of a Thai beverage company," Int. J. Trade, Econ. Financ., vol. 5, no. 5, pp. 445-448, 2014.

[11] K. L. Keller, "Unlocking the power of Integrated Marketing Communications: How integrated is your IMC program?," J. Advert., vol. 45, no. 3, pp. 286-301, 2016.

[12] B. Yoo, N. Donthu, and S. Lee, "An examination of selected marketing mix elements and brand equity," J. Acad. Mark. Sci., vol. 28, no. 2, pp. 195-211, 2000 . 
[13] I. Buil, L. de Chernatony, and E. Martínez, "Examining the role of advertising and sales promotions in brand equity creation," J. Bus. Res., vol. 66, no. 1, pp. 115-122, 2013

[14] U. Sekaran, Research Methods For Business: Metodologi Penelitian Untuk Bisnis, Book 2. 2006.

[15] S. Sugiyono, Metode Penelitian Kuantitatif dan Kualitatif dan R\&D. 2010.

[16] D. A. Aaker, "Measuring brand equity across products and markets," Calif. Manage. Rev., vol. 38, no. 3, pp. 102-120, 1996.

[17] P. Kotler and G. Armstrong, Principles of Marketing, Global Edition, 17 edition. Pearson Education Limited, 2018.

[18] I. H. Damarjati, A. Kusumawati, and M. K. Mawardi, "The influence of Integrated Marketing Communication on Brand Equity and Purchase Decision," J. Adm. Bisnis, vol. 34, no. 1, pp. 2937, 2014.

[19] M. Amaretta and E. Hendriana, "The effect of marketing communications on customer based brand equity," 2nd Int. Res. Symp. Serv. Manag., vol. 1, no. 1, p. 13, 2015.

[20] P. Anabila, "Integrated marketing communications, brand equity, and business performance in microfinance institutions: An emerging market perspective," J. Mark. Commun., vol. 26, no. 3, pp. 229-242, 2020.
[21] J. Ratnatunga and M. T. Ewing, "The brand capability value of Integrated Marketing Communication (IMC)," J. Advert., vol. 34, no. 4, pp. 25-40, 2005.

[22] K. L. Keller, "Building strong brands in a modern marketing communications environment," J. Mark. Commun., vol. 15, no. 2-3, pp. 139-155, 2009.

[23] R. S. Ebrahim, "The role of trust in understanding the impact of social media marketing on brand equity and brand loyalty," J. Relatsh. Mark., vol. 19, no. 4, pp. 287-308, 2020.

[24] K. Y. Koay, D. L. T. Ong, K. L. Khoo, and H. J. Yeoh, "Perceived social media marketing activities and consumer-based brand equity: Testing a moderated mediation model," Asia Pacific J. Mark. Logist., 2020.

[25] M. Bruhn, V. Schoenmueller, D. B. Schäfer, M. Bruhn, V. Schoenmueller, and D. B. Scha, "Are social media replacing traditional media in terms of brand equity creation?," Manag. Res. Rev., vol. 35, no. 9, pp. 770-790, 2015.

[26] S. Madhavaram, V. Badrinarayanan, and R. E. McDonald, "Integrated Marketing Communication (IMC) and brand identity as critical components of brand equity strategy: A conceptual framework and research propositions," J. Advert., vol. 34, no. 4, pp. 69-80, 2005. 